\title{
Toxicity and genotoxicity of water and sediment from streams on dotted duckweed (Landoltia punctata)
}

\author{
Factori, R. ${ }^{a *}$, Leles, SM. ${ }^{a}$, Novakowski, GC. ${ }^{b, c}$, Rocha, CLSC. ${ }^{a}$ and Thomaz, SM. ${ }^{b}$ \\ a'Laboratório de Genética Molecular e do Desenvolvimento, Programa de Pós-graduação em Biologia Comparada, \\ Universidade Estadual de Maringá - UEM, Av. Colombo, 5790, CEP 87020-900, Maringá, PR, Brazil \\ bNúcleo de Pesquisa em Limnologia e Aqüicultura, Universidade Estadual de Maringá - UEM, \\ Av. Colombo, 5790, CEP 87020-900, Maringá, PR, Brazil \\ 'Faculdade Ingá, Rodovia PR 317, 6114, CEP 87035-510, Maringá, PR, Brazil \\ *e-mail: rodrigo.factori@gmail.com
}

Received: March 11, 2013 - Accepted: July 16, 2013

(With 6 figures)

\begin{abstract}
Most rivers are used as a source to supply entire cities; the quality of water is directly related to the quality of tributaries. Unfortunately men have neglected the importance of streams, which receive domestic and industrial effluents and transport nutrients and pesticides from rural areas. Given the complexity of the mixtures discharged into these water bodies, this study aimed to evaluate the quality of water and sediment of ten tributaries of Pirapó River, in Maringá, Paraná State, Brazil. To this end, the free-floating macrophyte Landoltia punctata (G. Meyer) Les \& D.J.Crawford was used as test organism in microcosm, and the toxicity of water and sediment samples was evaluated by the relative growth rate, dry/fresh biomass ratio, and genotoxic effects (comet assay). Samples of water and sediment of each stream were arranged in microcosms with L. punctata. Seven days later, plants were collected for analysis. Nutrient levels were higher than the reference location, indicating eutrophication, but the results indicated a toxic effect for only three streams, and a genotoxic effect for all streams.
\end{abstract}

Keywords: Ecotoxicology, aquatic macrophyte, microcosm, anthropogenic pollution, comet assay.

\section{Toxicidade e genotoxicidade da água e sedimentos dos córregos em lentilha d'água (Landoltia punctata)}

\begin{abstract}
Resumo
Muitos rios são utilizados como fonte de abastecimento de cidades inteiras e a qualidade de suas águas está relacionada diretamente à qualidade de seus afluentes. Infelizmente córregos têm sua importância negligenciada pelo homem sendo alvo de despejos domésticos e industriais e também do carreamento de nutrientes e pesticidas das áreas rurais. Diante da complexidade das misturas que atingem estes corpos d'água, o presente estudo teve por objetivo avaliar a qualidade da água e do sedimento de dez afluentes do rio Pirapó no município de Maringá, Estado do Paraná. Utilizou-se a macrófita aquática flutuante Landoltia punctata (G. Meyer) Les \& D.J.Crawford como organismo teste em microcosmos, sendo que a toxicidade das amostras de água e sedimento foi avaliada pela taxa de crescimento relativo, pelo índice de biomassa seca por fresca, e pelos efeitos genotóxicos (ensaio de cometa). Amostras de água e sedimento de cada córrego foram dispostos em microcosmos com L. punctata. Após 7 dias as plantas foram coletadas para as análises. Os níveis de nutrientes foram maiores que o do local de referência indicando eutrofização; porém, os resultados indicaram efeito tóxico em apenas três dos córregos e genotóxico em todos os córregos.
\end{abstract}

Palavras-chave: Ecotoxicologia, macrófita aquática, microcosmos, poluição antrópica, ensaio de cometa.

\section{Introduction}

Pollutants can affect organisms in different ways. Many of them are toxic, and some of them may cause loss of genomic stability by altering the balance in chromatin metabolism. They are classified as genotoxic (Barlow et al., 2006; Marple et al., 2004). Several substances can react directly with DNA, causing lesions (Butterworth, 2006), or even preventing the DNA repair (Marple et al., 2004), subsequently causing mutations, chromosomal aberrations and/or changes in chromosome number (Butterworth, 2006). Some genotoxic agents have carcinogenic potential (Butterworth, 2006).

Because of the large number of pollutants, environments are usually affected by mixtures, which can be evaluated by ecotoxicological analysis, in order to recognize the 
harmfulness to biota of chemical substances, isolated or in form of mixtures (Knie and Lopes, 2004). Analysis are carried out with biological models that have the advantage of responding to levels below the detectable limit by methods of chemical analysis and possible synergism between different agents (Knie and Lopes, 2004).

Currently, for genotoxic evaluation, the comet assay is well defined. It has shown to be a valuable tool for being simple, versatile, of rapid execution, visual and highly sensitive to detect DNA lesions (Dhawan et al., 2009). This assay has been largely employed in genotoxic tests and can be applied to different models, from bacteria to man, to different tissues and cells, aiming to evaluate the genotoxic potential of substances and/ or environmental conditions: terrestrial, aquatic and aerial (Dhawan et al., 2009; Díaz et al., 2009; Prá et al., 2005; Kammann et al., 2001, 2004; Sriussadaporn et al., 2003; Poli et al., 1999).

In this context, this study aimed to evaluate the environmental quality of ten streams. They are important for being tributaries of Pirapó River, that supplies the city of Maringá. In this evaluation, in addition to physical and chemical factors such as $\mathrm{pH}$, temperature, conductivity, dissolved oxygen, total nitrogen and phosphorus, responses were analyzed from the free-floating aquatic macrophyte Landoltia punctata (G. Meyer) Les \& D.J.Crawford, considering its relative growth rate, dry/fresh biomass ratio as indicative of eutrophication or toxic effect. Potential genotoxic of water and sediment samples were also measured by the comet assay technique. It is expected that the present study contribute as a source of data to warn authorities and for proposals of improvement measures to these water bodies.

\section{Material and Methods}

\subsection{Study area}

Pirapó River basin is in the third plateau of the Paraná State, with a catchment area of about $5.076 \mathrm{Km}^{2}$, located between the latitudes $22^{\circ} 30^{\prime}$ and $23^{\circ} 30^{\prime} \mathrm{S}$ and longitudes $51^{\circ} 15^{\prime}$ and $52^{\circ} 15^{\prime} \mathrm{W}$. It encompasses 28 towns; at least 14 of them are supplied by this river, including Maringá (Peruço, 2004), which extends over the watershed ridge between Pirapó and Ivaí rivers basins, and because of this, numerous streams arise out within the urban perimeter of the city, being under the urban influence on their physical, chemical and biological characteristics (Cunico, 2010). For this study, were sampled 10 tributary streams of Pirapó River, situated on the same soil type, within the city of Maringá (Figure 1). These streams were classified into rural and urban, according to Kühl (2009) (Table 1).

\subsection{Sampling}

Samples of water and sediment were collected in November 2010, at nearby sites of 10 streams. In order to obtain results about the effect of pollutants in relation to a non-impacted area, we used a reference location instead of artificial means. The headwaters of Tagaçaba Stream were chosen as a reference location for being located inside a forest and for not receiving effluents or runoff from agricultural areas. Samplings were performed within three days without rainfall (Table 1).

Samples of water and sediment were collected in November 2010, at intermediate sites of 10 streams. The headwaters of Tagaçaba Stream was chosen as a reference location for being located inside a forest and for not receiving effluents or runoff from agricultural areas. Samplings was performed within three days without rainfall (Table 1).

The method employed to collect samples was based on Knie and Lopes (2004). Water was taken from under the water surface using two plastic vials of 3 liters. Sediment was collected and placed in glass vials with a capacity of $1 \mathrm{~kg}$. These samples were subjected to tests within five hours after collection, in order to minimize possible effects caused by physic-chemical and biochemical changes.

\subsection{Physical and chemical parameters}

Simultaneously to water and sediment sampling, conductivity, $\mathrm{pH}$, dissolved oxygen (DO), dissolved oxygen saturation and temperature (Table 2) were measured. One of the water samples of each stream was taken to the Laboratory of Agrochemistry and Environment from the State University of Maringá for the quantification of total nitrogen $(\mathrm{mg} / \mathrm{l})$ and total phosphorus $(\mathrm{mg} / \mathrm{l})$.

\subsection{Test organism}

The free-floating aquatic macrophyte L. punctata was selected for tests for being a native species, easily found in the study area, it is a non-endemic species and has wide distribution in the Paraná State and Atlantic Forest (Coelho, 2010). Like other duckweeds, it is tiny, allowing its growth in microcosms. Besides, the predominance of vegetative reproduction enables to obtain a genetically homogeneous population of plants, which is ideal for genotoxic analysis. It also has a very rapid growth, providing significant results in a short time when subjected to phytotoxicity tests, and allowing efficient estimates when subjected to comet assay (Babić et al., 2009; Radić et al., 2010).

Plants used in the present study came from an initial sample collected in nature, in Maringá, six months before the experiments and grown in plastic tanks for propagation.

\subsection{Microcosms}

Plastic trays $(20 \mathrm{x} 10 \mathrm{x} 4 \mathrm{~cm})$ comprised the microcosms. Ten trays were used for each stream, with five repetitions for water and five for sediment. In each tray, $400 \mathrm{ml}$ water of each stream were added. Sediment was distributed in a way to reach the height of $1 \mathrm{~cm}$, and distilled water was added to achieve a water depth of $1 \mathrm{~cm}$. All microcosms received one gram of macrophyte previously acclimated to the test conditions. Microcosms were randomly arranged in a greenhouse (Oikos, UEM) with a photoperiod of 14 hours, protected from direct sunlight with a $2 \mathrm{~mm}$ mesh screen to control the temperature and loss of water by evaporation. The temperature varied between 30 and $25^{\circ} \mathrm{C}$. 


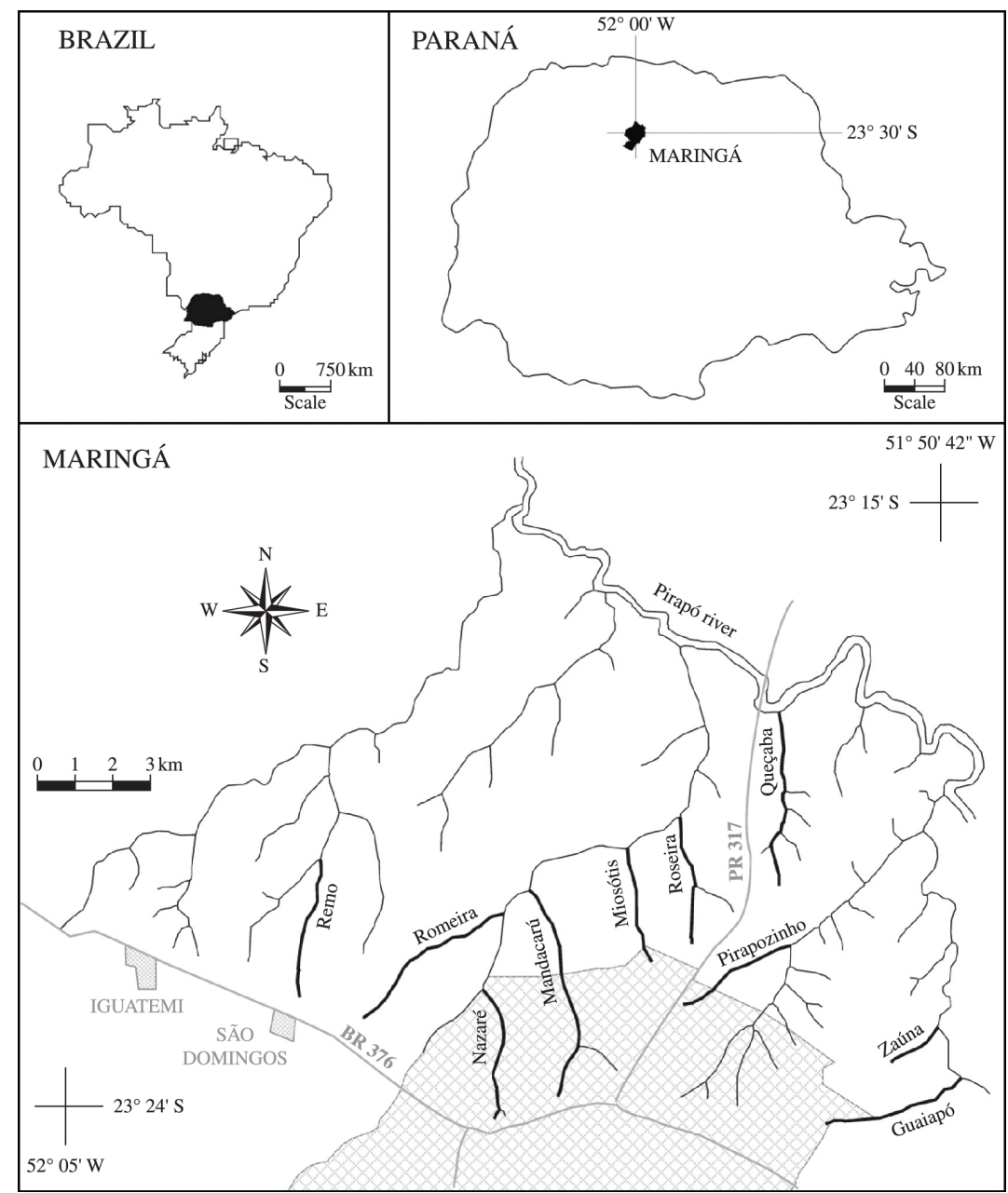

Figure 1. Location of the ten studied streams.

Table 1. Streams, geographic coordinates and altitude of sampling sites $(\mathrm{C}=$ control, $\mathrm{R}=$ rural, $\mathrm{U}=$ urban $)$.

\begin{tabular}{|c|c|c|c|}
\hline Stream & Classification & Coordinates & Altitude (m) \\
\hline Tagaçaba & $\mathrm{C}$ & $23^{\circ} 29^{\prime} 20,98^{\prime \prime S} 52^{\circ} 01^{\prime} 11,27^{\prime \prime} \mathrm{W}$ & 508 \\
\hline Água Queçaba & $\mathrm{R}$ & $23^{\circ} 19^{\prime} 04,41^{\prime \prime S} 51^{\circ} 53^{\prime} 29,35^{\prime \prime} \mathrm{W}$ & 371.3 \\
\hline Água da Roseira & $\mathrm{R}$ & $23^{\circ} 20^{\prime} 56,30^{\prime \prime} \mathrm{S} 51^{\circ} 54^{\prime} 52,31^{\prime \prime} \mathrm{W}$ & 404.8 \\
\hline Remo & $\mathrm{R}$ & $23^{\circ} 21^{\prime} 39,26^{\prime \prime} \mathrm{S} 52^{\circ} 01^{\prime} 02,48^{\prime \prime} \mathrm{W}$ & 442 \\
\hline Romeira & $\mathrm{R}$ & $23^{\circ} 22^{\prime} 04,05^{\prime \prime S} 51^{\circ} 58^{\prime} 43,50^{\prime \prime} \mathrm{W}$ & 455.5 \\
\hline Zaúna & $\mathrm{R}$ & $23^{\circ} 23^{\prime} 47,36^{\prime \prime} \mathrm{S} 51^{\circ} 51^{\prime} 02,09$ 'W & 450.5 \\
\hline Guaiapó & $\mathrm{U}$ & $23^{\circ} 24^{\prime} 44,54 ” S 51^{\circ} 51^{\prime} 13,83^{\prime \prime} \mathrm{W}$ & 497 \\
\hline Mandacaru & $\mathrm{U}$ & $23^{\circ} 23^{\prime} 05,24^{\prime \prime} \mathrm{S} 51^{\circ} 56^{\prime} 49,85^{\prime \prime} \mathrm{W}$ & 430.5 \\
\hline Miosótis & $\mathrm{U}$ & $23^{\circ} 21^{\prime} 54,50^{\prime} \mathrm{S} 51^{\circ} 55^{\prime} 37,35^{\prime \prime} \mathrm{W}$ & 414.5 \\
\hline Nazaré & $\mathrm{U}$ & $23^{\circ} 24^{\prime} 04,64^{\prime \prime} \mathrm{S} 51^{\circ} 58^{\prime} 03,57^{\prime \prime} \mathrm{W}$ & 459.9 \\
\hline Água do Pirapó & $\mathrm{U}$ & $23^{\circ} 22^{\prime} 24,31^{\prime \prime S} 51^{\circ} 53$ '48,58”W & 446.9 \\
\hline
\end{tabular}

\subsection{Mass assay}

Initial fresh biomass $(1 \mathrm{~g})$ was added to each microcosm, after slightly drying with paper towel. In the same way, after 7 days macrophytes were removed from microcosms and weighed again, in order to obtain the final fresh biomass; they were then wrapped in paper envelopes and oven-dried until achieving constant weight, the final dry biomass $\left(\mathrm{DB}_{\mathrm{f}}\right)$. The initial dry biomass $\left(\mathrm{DB}_{\mathrm{i}}\right)$ was estimated by the proportion of the initial fresh biomass and dry biomass obtained from a portion of macrophyte of the start of testing. We then calculated the relative growth rate (RGR) $=\left(\operatorname{lnDB}_{\mathrm{f}}-\operatorname{lnDB} \mathrm{B}_{\mathrm{i}}\right) / \mathrm{t}$, where $\mathrm{t}$ is the period of 7 days. Ratio 
Table 2. Physical and chemical parameters of samples. TA=Tagaçaba; QU= Água Queçaba; RS=Água da Roseira; $\mathrm{RE}=$ Remo; RM=Romeira; ZA=Zaúna; GU=Guaiapó; MA=Mandacaru; MI=Miosótis; NA=Nazaré; PI=Água do Pirapó; $\mathrm{C}=$ control; $\mathrm{R}=$ rural; $\mathrm{U}=$ urban.

\begin{tabular}{|c|c|c|c|c|c|c|c|c|}
\hline \multirow{2}{*}{ Stream } & & Conductivity & Temperature & $\mathbf{O}_{2}$ & Saturation & \multirow{2}{*}{$\mathbf{p H}$} & Total N & \multirow{2}{*}{$\begin{array}{c}\text { Total P } \\
\mathrm{mg} / \mathrm{L}\end{array}$} \\
\hline & Classification & $\mathrm{mS} / \mathrm{cm}$ & $\mathbf{C}^{\circ}$ & $\mathrm{mg} / \mathrm{L}$ & $\mathrm{O}_{2} \%$ & & $\mathrm{mg} / \mathrm{L}$ & \\
\hline TA & $\mathrm{C}$ & 44.0 & 24.0 & 7.57 & 88.4 & 6.04 & 60.7 & 0.09 \\
\hline QU & $\mathrm{R}$ & 180.4 & 22.3 & 7.87 & 90.5 & 5.89 & 51.3 & 0.09 \\
\hline $\mathrm{RS}$ & $\mathrm{R}$ & 135.0 & 22.0 & 7.38 & 83.8 & 8.18 & 140.0 & 0.26 \\
\hline $\mathrm{RE}$ & $\mathrm{R}$ & 126.4 & 22.0 & 7.87 & 90.0 & 5.60 & 53.3 & 0.10 \\
\hline $\mathrm{RM}$ & $\mathrm{R}$ & 83.7 & 22.3 & 6.06 & 70.2 & 5.89 & 53.3 & 0.05 \\
\hline $\mathrm{ZA}$ & $\mathrm{R}$ & 122.4 & 22.6 & 7.74 & 88.9 & 6.17 & 51.3 & 0.06 \\
\hline $\mathrm{GU}$ & $\mathrm{U}$ & 191.6 & 24.9 & 6.88 & 82.6 & 6.07 & 46.7 & 0.08 \\
\hline MA & $\mathrm{U}$ & 176.8 & 22.8 & 7.96 & 88.0 & 7.59 & 94.0 & 0.04 \\
\hline MI & $\mathrm{U}$ & 137.0 & 23.4 & 7.55 & 87.8 & 8.05 & 158.7 & 0.06 \\
\hline NA & $\mathrm{U}$ & 299.0 & 23.7 & 6.50 & 75.8 & 5.97 & 53.3 & 0.14 \\
\hline PI & $\mathrm{U}$ & 147.1 & 25.7 & 6.85 & 83.8 & 7.43 & 149.3 & 0.07 \\
\hline
\end{tabular}

between final dry biomass and final fresh biomass $\left(\mathrm{DB}_{\mathrm{f}} /\right.$ $\mathrm{FB}_{\mathrm{f}}$ ) was also calculated, which can also be an indicative of plant stress (Perfus-Barbeoch et al., 2002).

\subsection{Genotoxicity assay}

Ten fronds were randomly collected from each microcosm, rinsed with distilled water and dried with paper towel to be used in comet assay, according to procedure of Navarrete et al. (1997) with modifications. Plants were not cut, but crushed with a metallic aste against the wall of the Eppendorf tubes with $0.5 \mathrm{~mL}$ PBS, of which $120 \mu 1$ was taken to another Eppendorf tube with $120 \mu$ l low melting point agarose at $1 \%$. After homogenization, the volume was distributed onto two slides previously coated with normal melting point agarose at $1.5 \%$ and then a coverslip was placed over each slide to spread the suspension of nuclei and taken to refrigerator for five minutes to gel low melting point agarose; after this time interval, coverslips were removed. Afterwards, the processes of electrophoresis, neutralization and fixation were carried out, based on Navarrete et al. (1997).

At the time of analysis with a fluorescence microscope under 200X magnification (Zeiss Axioskop2 Plus), slides were stained with $2 \%$ ethidium bromide. Random fields were examined on the slide until totaling 50 nuclei or more. Nuclei were classified into five levels (0-4) from which was calculated the damage index, which is the sum of nuclei multiplied by the level that they occupy, divided by total nuclei multiplied by 100 , so that this score ranges from 0 to 400 , if all nuclei have had damage 0 or 4 , respectively. The damage frequency was also calculated, it corresponds to the percentage of damaged nuclei (1-4) divided by the total nuclei (0-4) multiplied by 100 (Collins et al., 1997).

\subsection{Statistical analysis}

In order to evaluate possible differences between growth rate of $L$. punctata treated with only water or sediment of each stream, a two-way analysis of variance was run, and a post-hoc Dunnett's test was applied to compare with the reference location. Data obtained in the damage index of comet assay and dry/fresh biomass ratio were transformed as proposed by Dias and Barros (2009) to meet normality and homoscedasticity. These analyses were performed using the software Statistica 7.1 (StatSoft).

To check correlations between abiotic data and growth rate/comet assay with $L$. punctata, a Principal Component Analysis (PCA) was employed. With the Broken-Stick criterion, axes 1 and 2 were retained for interpretation. This analysis was run on the software PC-ORD 5.0 (MjM Software).

\section{Results}

\subsection{Abiotic variables}

The lowest value of conductivity was observed for the reference location (Tagaçaba). The highest values were found for streams Nazaré, Guaiapó, Queçaba and Mandacaru. In relation to saturation of dissolved oxygen, Romeira, Nazaré, Guaiapó, Água da Roseira and Água do Pirapó have stood out by lower values, from 70 to $84 \%$. Other streams (Tagaçaba, Água Queçaba, Remo, Zaúna, Mandacaru and Miosótis) had values around 90\%. Higher concentrations of total nitrogen were registered in streams Miosótis, Água do Pirapó and Água da Roseira. Values of total phosphorus were lower for streams Mandacaru (around 40\% from reference location value), Romeira, Zaúna and Miosótis (around 60\% from reference location value), Água do Pirapó and Guaiapó (around 75\% from reference location value). Higher values of this parameter were verified in the streams Nazaré and Água da Roseira with $139 \%$ and $264 \%$ compared with the reference location (Table 2).

\subsection{Relative growth rate (RGR) and dry/fresh biomass ratio}

According to ANOVA results, mean values of RGR were significantly different between water and sediment, with higher values in this latter $\left(\mathrm{F}_{10 ; 88}=14.146\right.$; $\left.\mathrm{p}<0.001\right)$. A significant difference was found between RGR values of 
streams $\left(\mathrm{F}_{10 ; 88}=19.269 ; \mathrm{p}<0.001\right)$. The post-hoc Dunnett's test $\left(d_{10 ; 88}\right)$ indicated that the streams Água da Roseira, Mandacaru, Miosótis and Água do Pirapó have presented significantly lower RGR than the reference location, for both water and sediment (Figure 2).

Mean values of the dry/fresh biomass ratio were significantly different between water and sediment, with higher values for water $\left(\mathrm{F}_{10 ; 88}=30.57 ; \mathrm{p}<0.001\right)$. Also, mean values were different between streams $\left(\mathrm{F}_{10 ; 88}=20.82\right.$; $\mathrm{p}<0.001)$, and according to Dunnett's test $\left(d_{10 ; 88}\right)$, water from streams Água da Roseira and Água do Pirapó and sediment from streams Água da Roseira, Miosótis and Água do Pirapó, have been significantly higher than the reference location (Figure 3).

\subsection{Comet assay}

In genotoxic evaluation, the damage index of comet assay tested by a two-way ANOVA evidenced significant interaction between variables stream and water-sediment $\left(F_{10 ; 198}=2.98 ; p<0.01\right)$. Mean values were not significantly

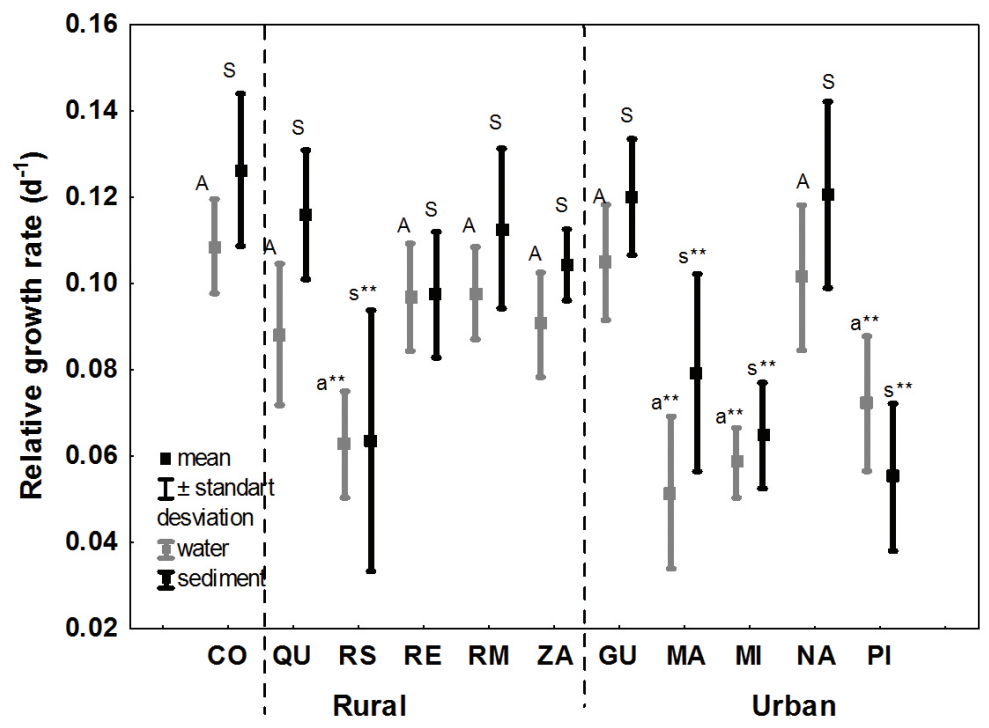

Figure 2. Relative growth rate (RGR). Lowercase letters indicate significant difference from the control $(* *=\mathrm{p}<0.01)$. $\mathrm{CO}=$ Control; $\mathrm{GU}=$ Guaiapó; MA=Mandacaru; MI=Miosótis; NA=Nazaré; PI=Água do Pirapó; QU=Queçaba; RE=Remo; $\mathrm{RM}=$ Romeira; RS=Águas da Roseira; ZA=Zaúna.

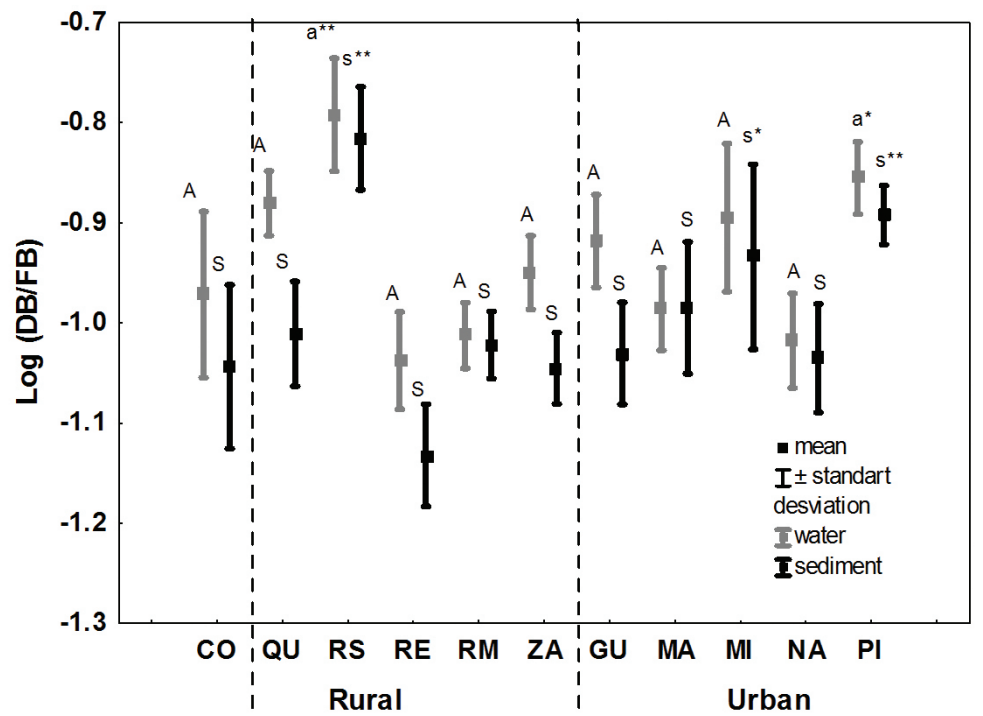

Figure 3. Biomass index (log scale). Lowercase letters indicate significant difference from the control $(*=\mathrm{p}<0.05$; $* *=\mathrm{p}<0.01) . \mathrm{CO}=$ Control; $\mathrm{GU}=$ Guaiapó; MA=Mandacaru; MI=Miosótis; NA=Nazaré; PI=Água do Pirapó; QU=Queçaba; $\mathrm{RE}=$ Remo; $\mathrm{RM}=$ Romeira; $\mathrm{RS}=\mathrm{A} g u a s$ da Roseira; $\mathrm{ZA}=\mathrm{Zaúna}$. 
different between water and sediment $\left(\mathrm{F}_{10 ; 198}=1.28 ; \mathrm{p}>0.05\right)$, but were statistically different between streams $\left(\mathrm{F}_{10 ; 198}=9.14\right.$; $\mathrm{p}<0.001)$. According to Dunnett's test $\left(d_{10: 198}\right)$, only sediment from streams Zaúna and Água do Pirapó were not different from the reference location, the others were significantly higher than the reference location (Figure 4).

The damage frequency to water and sediment diverged among themselves in relation to streams (significant interaction $\mathrm{F}_{10 ; 198}=2.569 ; \mathrm{p}=0.0061$ ). Mean values were not significantly different between water and sediment $\left(F_{10 ; 198}=0.080 ; p=0.778\right)$, however they were significantly different among streams $\left(\mathrm{F}_{10 ; 198}=11.915 ; \mathrm{p}<0.001\right)$. In order to identify streams different from the reference location, the Dunnett's test $\left(d_{10 ; 198}\right)$ was applied. It showed that the water of streams Água Queçaba, Mandacaru, Miosótis and Nazaré, and sediment from streams Remo, Zaúna, Miosótis and Água do Pirapó were not statistically different from the reference location; the others were significantly greater in relation to the reference location (Figure 5).

\subsection{Principal component analysis}

Subsequently, to identify possible correlations between variables and to identify the most important characteristic for the differentiation among streams, a principal component

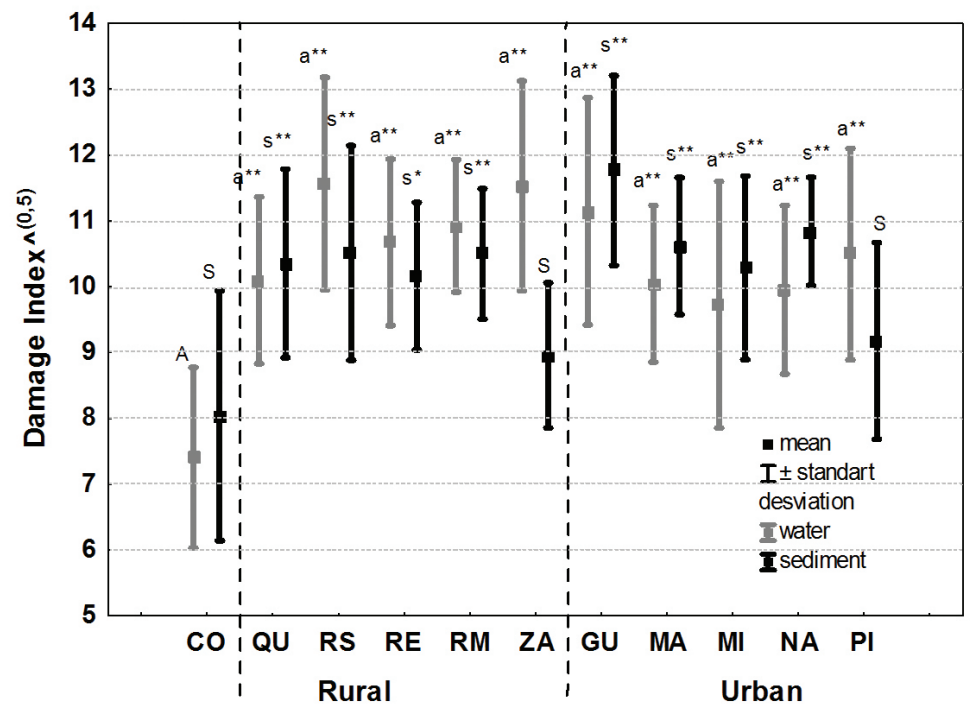

Figure 4. Damage index (square root). Lowercase letters indicate significant difference from the control $(*=\mathrm{p}<0.05$; $* *=\mathrm{p}<0.01) . \mathrm{CO}=\mathrm{Control}$; $\mathrm{GU}=$ Guaiapó; $\mathrm{MA}=$ Mandacaru; $\mathrm{MI}=$ Miosótis; NA=Nazaré; PI=Água do Pirapó; QU=Queçaba; $\mathrm{RE}=$ Remo; RM=Romeira; RS=Águas da Roseira; ZA=Zaúna.

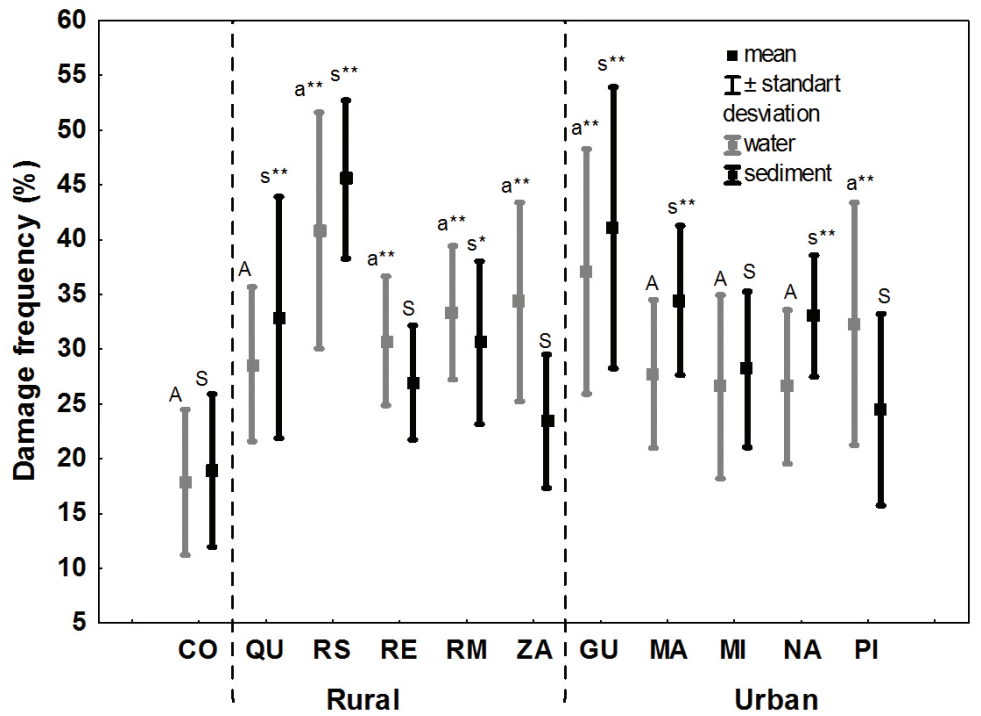

Figure 5. Damage frequency. Lowercase letters indicate significant difference from the control $(*=\mathrm{p}<0.05 ; * *=\mathrm{p}<0.01)$. $\mathrm{CO}=$ Control; $\mathrm{GU}=$ Guaiapó; MA=Mandacaru; $\mathrm{MI}=$ Miosótis; NA=Nazaré; PI=Água do Pirapó; QU=Queçaba; RE=Remo; $\mathrm{RM}=$ Romeira; $\mathrm{RS}=$ Águas da Roseira; ZA=Zaúna. 
analysis (PCA) was performed with abiotic and biotic variables, followed by ANOVA on axes retained for analysis. Firstly, the ordination presented correlations somewhat consistent with the literature, data from the Água da Roseira Stream have caused this divergence since they presented the highest concentration of phosphorus, but the plant growth was low in this sample, probably a toxic effect. In this way, these data were removed and PCA was run again (Figure 6). For this new analysis, axes 1 and 2 were retained for interpretation and explained $33.4 \%$ and $21.3 \%$ of variance, respectively. This time the total phosphorus presented the expected correlation with the growth of macrophyte as well as temperature and dissolved oxygen. The three variables $\mathrm{pH}$, total nitrogen and biomass index were the most negatively influencing the ordination for the PCA1. The RGR and total phosphorus have positively influenced the ordination of the PCA1. The concentration and saturation of dissolved oxygen were the variables that most influenced negatively the ordination of PCA2, and temperature, positively. ANOVA evidenced significant difference between streams, for both PCA $1\left(\mathrm{~F}_{9 ; 40}=242.5401\right.$; $\mathrm{p}<0.001)$ and PCA $2\left(\mathrm{~F}_{9 ; 40}=677.8497 ; \mathrm{p}<0.001\right)$. After this, the Dunnett's test $\left(\dot{d}_{9: 40}\right)$ at a significance level of 0.05 has indicated that, for PCA 1, the streams Água do Pirapó, Mandacaru, Miosótis and Zaúna have negatively differed from the reference location, with higher $\mathrm{pH}$, total nitrogen and dry/fresh biomass ratio. Nazaré, Remo and Romeira streams have differed positively from the reference location, with higher RGR and total phosphorus. For the PCA 2, Água do Pirapó, Guaiapó, Miosótis, Romeira and Nazaré streams have differed positively from the reference location, with higher temperature values. Queçaba, Remo and Zaúna streams have differed negatively from the reference location, with higher concentration and saturation of oxygen.

\section{Discussion}

Although high values of conductivity may be an indirect indicative of pollution (Graça and Coimbra, 1998), as expected, the reference location showed low conductivity, but this parameter did not influence linearly the biological parameters tested on L. punctata. In agreement with Scheffer and Busch (2010), dissolved oxygen values below the saturation are especially related to increased organic matter in the water body; in this way it can indicate sewage discharge. In this aspect, the Romeira Stream presented the lowest saturation, despite being a rural stream, possibly with little or without domestic sewage, and this result was probably due to the discharge of pig farm waste. Nazaré Stream presented the second lowest saturation probably owed to the effect of domestic sewage, because, according to Cunico (2010) this stream has $100 \%$ urbanization in its microbasin. The other streams presented oxygen saturation closer to the reference location and despite the stream Mandacaru has characteristics of waste discharge similar to the Nazare Stream (Kühl, 2009) with 82.5\% urbanization in its microbasin (Cunico, 2010), it presented an oxygen saturation higher than the Nazaré Stream, probably because of a rapid stretch near the sampling site. Regarding the concentration of dissolved oxygen, all streams are categorized into the class 1 , according to resolution 357/2005 of CONAMA (>6mg/l) (Brasil, 2006).

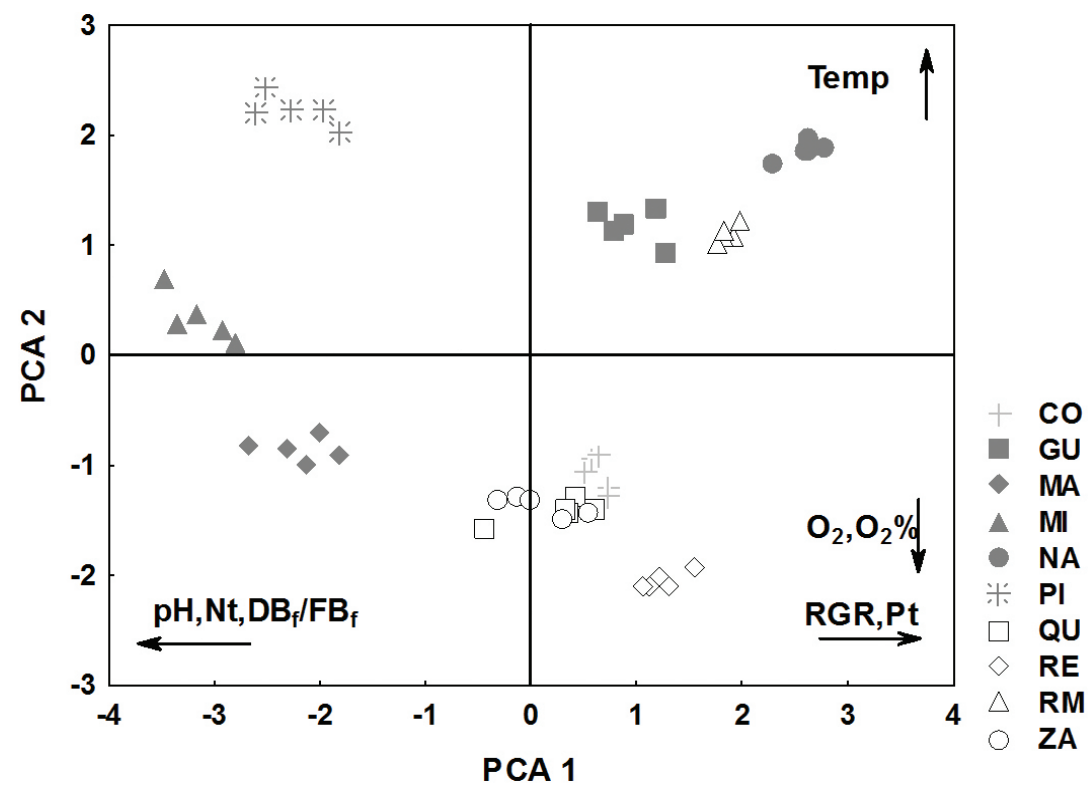

Figure 6. PCA, arrows indicate variables that most influence the ordination along these two axes. Nt=total nitrogen; $\mathrm{O}_{2}=$ dissolved oxygen; $\mathrm{O}_{2} \%=$ dissolved oxygen saturation; $\mathrm{Pt}=$ total phosphorus; $\mathrm{DB}_{\mathrm{f}} / \mathrm{FB}_{\mathrm{f}}=\mathrm{dry} /$ fresh biomass ratio; $\mathrm{RGR}=$ relative growth rate in terms of dry biomass; Temp=temperature; $\mathrm{CO}=\mathrm{Control}$; $\mathrm{GU}=\mathrm{Guaiapó}$; $\mathrm{MA}=\mathrm{Mandacaru}$; MI=Miosótis; NA=Nazaré; PI=Água do Pirapó; QU=Queçaba; RE=Remo; RM=Romeira; ZA=Zaúna. 
According to Esteves (1998), low concentrations of nitrogen compounds can work as a limiting factor for aquatic macrophytes, but in this study, total nitrogen has negatively influenced the RGR of macrophytes, and positively the biomass index, indicating a toxic effect for L. punctata, which was possibly associated with the effect of nitrogen in form of ammonia. The relative growth rate of duckweeds linearly decreases with increasing ammonia, leading to death in concentrations above $8 \mathrm{mg} / 1$ (Körner et al., 2003). Onaindia et al. (1996) reported that ammonia nitrogen usually derives from discharges and is commonly associated with absence of macrophytes. Moreover, ammonia nitrogen is the reduced form of nitrogen and indicates recent pollution of the water body (Von Sperling, 1996).

The $\mathrm{pH}$ also had a negative correlation with RGR and positive with $\mathrm{DB}_{\mathrm{f}} / \mathrm{FB}_{\mathrm{f}}$, but the $\mathrm{pH}$ should not have had a direct influence on these parameters as all streams were within the range of 5-9 indicated as suitable for the growth of duckweeds by Radić et al. (2010). The positive correlation of $\mathrm{pH}$ with total nitrogen suggests once again the predominance of the ammonia form, and in agreement with Dickson (1981) ammonia tends to make the $\mathrm{pH}$ alkaline. On the other hand, alkalinity shifts the ammonium/ammonia balance, increasing the concentration of ammonia that is toxic to duckweeds even at low concentrations, justifying its negative but indirect effect of $\mathrm{pH}$ on the macrophyte.

The results of RGR of L. punctata were positively influenced by phosphorus, corroborating the study of Kobayashi et al., (2008) who evidenced the phosphorus as a limiting factor for the growth of a floating macrophyte species. Although the stream Água da Roseira had presented the highest concentration of total phosphorus, this stream along with Mandacaru, Miosótis and Água do Pirapó streams, have presented mean RGR significantly lower than the reference location, for both water and sediment; these streams had higher concentration of total nitrogen and higher $\mathrm{pH}$. Mean values of RGR in sediment were higher than in water, and besides that there was no interaction between variables stream and water-sediment, pointing out that the sediment acts as a pool of nutrients that can be transferred to the water column similarly among streams. According to the resolution 357/2005 of CONAMA (Brasil, 2006) relative to total phosphorus, streams Remo and Nazaré are classified into class 3 and Água da Roseira Stream into class 4 , and the others into class 1 .

Considering the biomass index, the sediment from Miosótis Stream, water and sediment from Água da Roseira and Água do Pirapó streams presented mean values significantly higher than the reference location. According to Perfus-Barbeoch et al. (2002) this negative effect on the plant is the result of osmotic stress that reduces the growth and increases the dry/fresh biomass ratio. The other streams have not differed from the reference location, and in general, assays with water presented indices significantly higher than assays with sediment, perhaps due to the availability of nutrients by sediment, which occurs similarly among streams (without significant interaction).
Parameters RGR and DB/FB in this study were similar, but the RGR was more sensitive, indicating one more stream (Mandacaru) significantly different from the reference location.

As for the genotoxicity, almost all streams presented damage index of comet assay significantly higher than the reference location, except the sediment from Zaúna and Água do Pirapó streams. Results presented interaction between streams and water-sediment, indicating that streams presented possible genotoxic agents different in relation to the dynamics between water column and sediment. Although not significant, apparently, tests with water from rural streams tended to be more genotoxic than with sediment, and for urban streams, sediment tended to be more genotoxic than water. According to Esteves (1998), various compounds may concentrate in the sediment, this way, the sediment is important for assessing the ecosystem, also giving responses to previous contamination.

In relation to the damage frequency, water from four out of the ten streams studied (Água Queçaba, Mandacaru, Miosótis and Nazaré), and sediment of four out of the ten streams (Remo, Zaúna, Miosótis and Água do Pirapó) have not differed from the reference location. In the present study, the damage index showed to be more sensitive than damage frequency. This is because the damage frequency only considers the number of nuclei with damage, and in some cases, some cells can also have more severe damage, fact that is taken into account in the damage index.

The results obtained with the comet assay are very important because, according to Xu et al. (1998) and Wang and Freemark (1995), it has been demonstrated premutagenic and mutagenic activities in higher plants, and in algae they occur through mechanisms similar to those found in mammals. Zagatto and and Bertoletti (2006) stated that depending on the amount and location of mutations, they can cause diseases in individual and offspring, and can increase the incidence of cancer, hereditary, developmental, neurobehavioral and heart diseases, virulence of pathogens, in addition to the negative effect on biodiversity.

In this work the comet assay proved to be a fast, economic and reliable too; it and can be well employed in aquatic ecotoxicological studies, and applied to other organisms such as algae (Aoyama et al., 2003), flatworms (Guecheva et al., 2001) and fish (Grisolia et al., 2009).

These results indicate a risk for aquatic biota and for man, since these streams flow into the Pirapó River, which in turn, is responsible for supplying Maringa and several others cities that make up its basin (Peruço, 2004). However, further studies are necessary to verify possible contaminants and their origins specifically in these locations.

\section{References}

AOYAMA, K., IWAHORI, K. and MIYATA, N., 2003. Application of Euglena gracilis cells to comet assay: evaluation of DNA damage and repair. Mutation Research, vol. 538, no. 1-2, p. 155-162. http:// dx.doi.org/10.1016/S1383-5718(03)00113-X. PMid:12834764 
BABIĆ, M., RADIĆ, S., CVJETKO, P., ROJE, V., PEVALEKKOZLINA, B. and PAVLICA, M., 2009. Antioxidative response of Lemna minor plants exposed to thallium(I)-acetate. Aquatic Botany, vol. 91, no. 3, p. 166-172. http://dx.doi.org/10.1016/j. aquabot.2009.05.005.

BARLOW, S., RENWICK, AG., KLEINER, J., BRIDGES, JW., BUSK, L., DYBING, E., EDLER, L., EISENBRAND, G., FINKGREMMELS, J., KNAAP, A., KROES, R., LIEM, D., MÜLLER, DJ., PAGE, S., ROLLAND, V., SCHLATTER, J., TRITSCHER, A., TUETING, W. and WÜRTZEN, G., 2006. Risk assessment of substances that are both genotoxic and carcinogenic Report of an International Conference organized by EFSA and WHO with support of ILSI Europe. Food and chemical toxicology, no. 44, no. 10, p. 1636-1650. PMID: 16891049.

BUTTERWORTH, BE., 2006. A classification framework and practical guidance for establishing a mode of action for chemical carcinogens. Regulatory Toxicology and Pharmacology, vol. 45, no. 1, p. 9-23. http://dx.doi.org/10.1016/j.yrtph.2006.01.011. PMid:16530901

$<$ report>Brasil. Ministério do Meio Ambiente-MMA. Conselho Nacional do Meio Ambiente - CONAMA, 2006. Livro das Resoluções do CONAMA. 11. ed. Brasília: MMA. 808 p. $</$ report $>$

COELHO, MAN., 2010. As Angiospermas do Brasil. In FORZZA, RC., BAUMGRATZ, JFA., BICUDO, CEM., CARVALHO JUNIOR, AA., COSTA, A., COSTA, DP., HOPKINS, M., LEITMAN, PM., LOHMANN, LG., MAIA, LC., MARTINELLI, G., MENEZES, M., MORIM, MP., COELHO, MAN., PEIXOTO, AL., PIRANI, JR., PRADO, J., QUEIROZ, LP., SOUZA, VC., STEHMANN, JR., SYLVESTRE, LS., WALTER, BMT. and ZAPPI, D. (Orgs.). Catálogo de plantas e fungos do Brasil. Rio de Janeiro: Instituto de Pesquisas Jardim Botânico do Rio de Janeiro. p. 78-89.

COLLINS, AR., DOBSON, VL., DUSINSKÁ, M., KENNEDY, G. and STĚTINA, R., 1997. The comet assay: what can it really tell us? Mutation Research, vol. 375, no. 2, p. 183-193. http:// dx.doi.org/10.1016/S0027-5107(97)00013-4. PMid:9202728

CUNICO, AM., 2010. Efeitos da urbanização sobre a estrutura das assembléias de peixes em córregos do municipio de Maringá, Paraná, Brasil. Maringá: Universidade Estadual de Maringá. Dissertação de Mestrado em Ciências Ambientais.

DHAWAN, A., BAJPAYEE, M. and PARMAR, D., 2009. Comet assay: a reliable tool for the assessment of DNA damage in different models. Cell Biology and Toxicology, vol. 25, no. 1, p. 5-32. http://dx.doi.org/10.1007/s10565-008-9072-z. PMid:18427939

DIAS, LAS. and BARROS, WS., 2009. Biometria experimental. Viçosa: Editora UFV. 408 p.

DÍAZ, A., CARRO, S., SANTIAGO, L., ESTÉVEZ, J., GUEVARA, C., BLANCO, M., SÁNCHEZ, L., SÁNCHEZ, L., LÓPEZ, N., CRUZ, D., LÓPEZ, R., CUETARA, EB. and FUENTES, JL., 2009. Estimates of DNA strand breakage in bottlenose dolphin (Tursiops truncatus) leukocytes measured with the Comet and DNA diffusion assays. Genetics and Molecular Biology, vol. 32, no. 2, p. 367-372. http://dx.doi.org/10.1590/S1415-47572009005000030. PMid:21637693

DICKSON, AG., 1981. An exact definition of total alkalinity and a procedure for the estimation of alkalinity and total inorganic carbon from titration data. Deep-Sea Research, vol. 28, no. 6, p. 609-623. http://dx.doi.org/10.1016/0198-0149(81)90121-7.

ESTEVES, FA., 1998. Fundamentos de Limnologia. Rio de Janeiro: Editora Interciência. 602 p.
GRAÇA, MAS. and COIMBRA, CN., 1998. The elaboration of indices to assess biological water quality. A case study. Water Research, vol. 32, no. 2, p. 380-392. http://dx.doi.org/10.1016/ S0043-1354(97)00250-9.

GRISOLIA, CK., RIVERO, CL., STARLING, FL., SILVA, IC., BARBOSA, AC. and DOREA, JG., 2009. Profile of micronucleus frequencies and DNA damage in different species of fish in a eutrophic tropical lake. Genetics and Molecular Biology, vol. 32, no. 1, p. 138-143. http://dx.doi.org/10.1590/S141547572009005000009. PMid:21637659

GUECHEVA, T., HENRIQUES, JA. and ERDTMANN, B., 2001. Genotoxic effects of copper sulphate in freshwater planarian in vivo, studied with the single-cell gel test (comet assay). Mutation Research, vol. 497, no. 1-2, p. 19-27. http://dx.doi.org/10.1016/ S1383-5718(01)00244-3. PMid:11525904

KAMMANN, U., BISELLI, S., HÜHNERFUSS, H., REINEKE, N., THEOBALD, N., VOBACH, M. and WOSNIOK, W., 2004. Genotoxic and teratogenic potential of marine sediment extracts investigated with comet assay and zebrafish test. Environmental Pollution, vol. 132, no. 2, p. 279-287. http://dx.doi.org/10.1016/j. envpol.2004.04.021. PMid:15312940

KAMMANN, U., BUNKE, M., STEINHART, H. and THEOBALD, N., 2001. A permanent fish cell line (EPC) for genotoxicity testing of marine sediments with the comet assay. Mutation Research, vol. 498, no. 1-2, p. 67-77. http://dx.doi.org/10.1016/S13835718(01)00268-6. PMid:11673072

KNIE, JLW. and LOPES, EWB., 2004. Testes ecotoxicológicos: métodos, técnicas e aplicações. Florianópolis: Editora FATMA/ GTZ. 289 p.

KOBAYASHI, JT., THOMAZ, SM. and PELICICE, FM., 2008. Phosphorus as a limiting factor for Eichhornia crassipes growth in the upper Paraná river floodplain. Wetlands, vol. 28, no. 4, p. 905-913. http://dx.doi.org/10.1672/07-89.1.

KÖRNER, S., VERMAAT, JE. and VEENSTRA, S., 2003. The capacity of duckweed to treat wastewater: ecological considerations for a sound design. Journal of Environmental Quality, vol. 32, no. 5, p. 1583-1590. http://dx.doi.org/10.2134/jeq2003.1583. PMid: 14535298

KÜHL, AM., 2009. Avaliação ecotoxicológica da água e do sedimento de córregos da bacia do rio Pirapó (Maringá, PR) e Proposta de novo índice para a avaliação da qualidade dos cursos de água - Índice de Proteção da Vida Aquática modificado (IVAm). Maringá: Universidade Estadual de Maringá. Dissertação de Mestrado em Biologia Comparada.

MARPLE, T., LI, H. and HASTY, P., 2004. A genotoxic screen: rapid analysis of cellular dose-response to a wide range of agents that either damage DNA or alter genome maintenance pathways. Mutation Research, vol. 554, no. 1-2, p. 253-266. http://dx.doi. org/10.1016/j.mrfmmm.2004.05.004. PMid:15450423

NAVARRETE, MH., CARRERA, P., MIGUEL, M. and DE LA TORRE, C., 1997. A fast comet assay variant for solid tissue cells. The assessment of DNA damage in higher plants. Mutation Research, vol. 389, no. 2-3, p. 271-277. http://dx.doi.org/10.1016/ S1383-5718(96)00157-X. PMid:9093393

ONAINDIA, M., BIKUÑA, BG. and BENITO, I., 1996. Aquatic plants in relation to environmental factors in northern Spain. Journal of Environmental Management, vol. 47, no. 2, p. 123137. http://dx.doi.org/10.1006/jema.1996.0041. 
PERFUS-BARBEOCH, L., LEONHARDT, N., VAVASSEUR, A. and FORESTIER, C., 2002. Heavy metal toxicity: cadmium permeates through calcium channels and disturbs the plant water status. The Plant Journal, vol. 32, no. 4, p. 539-548. http://dx.doi. org/10.1046/j.1365-313X.2002.01442.x. PMid:12445125

PERUÇO, JD., 2004. Identificação das principais fontes poluidoras de afluentes da bacia do alto rio Pirapó. Maringá, Paraná. Maringá: Universidade Estadual de Maringá. Dissertação de Mestrado em Engenharia Química.

POLI, P., BUSCHINI, A., RESTIVO, FM., FICARELLI, A., CASSONI, F., FERRERO, I. and ROSSI, C., 1999. Comet assay application in environmental monitoring: DNA damage in human leukocytes and plant cells in comparison with bacterial and yeast tests. Mutagenesis, vol. 14, no. 6, p. 547-556. http://dx.doi. org/10.1093/mutage/14.6.547. PMid:10567029

PRÁ, D., LAU, AH., KNAKIEVICZ, T., CARNEIRO, FR. and ERDTMANN, B., 2005. Environmental genotoxicity assessment of an urban stream using freshwater planarians. Mutation Research, vol. 585, no. 1-2, p. 79-85. http://dx.doi.org/10.1016/j. mrgentox.2005.04.002. PMid:15897001

RADIĆ, S., STIPANIČEV, D., CVJETKO, P., MIKELIĆ, IL., RAJCIĆ, MM., ŠIRAC, S., PEVALEK-KOZLINA, B. and PAVLICA, M., 2010. Ecotoxicological assessment of industrial effluent using duckweed (Lemna minor L.) as a test organism. Ecotoxicology (London, England), vol. 19, no. 1, p. 216-222. http://dx.doi.org/10.1007/s10646-009-0408-0. PMid:19757030
SCHEFFER, EWO. and BUSCH, OMS., 2010. Qualidade da água. In GEALH, AM., MELO, MS. and MORO, RS. (Orgs.). Pitangui, rio de contrastes: seus lugares, seus peixes, sua gente. Ponta Grossa: Editora da UEPG. p. 43-52.

SRIUSSADAPORN, C., YAMAMOTO, K., FUKUSHI, K. and SIMAZAKI, D., 2003. Comparison of DNA damage detected by plant comet assay in roadside and non-roadside environments. Mutation Research, vol. 541, no. 1-2, p. 31-44. http://dx.doi. org/10.1016/S1383-5718(03)00177-3. PMid:14568292

VON SPERLING, M., 1996. Introdução à qualidade das águas e ao tratamento de esgotos. Belo Horizonte: Editora da Universidade Federal de Minas Gerais. 243 p.

WANG, W. and FREEMARK, K., 1995. The use of plants for environmental monitoring and assessment. Ecotoxicology and Environmental Safety, vol. 30, no. 3, p. 289-301. http://dx.doi. org/10.1006/eesa.1995.1033. PMid:7541343

XU, H., SWOBODA, I., BHALLA, PL., SIJBERS, AM., ZHAO, C., ONG, EK., HOEIJMAKERS, JH. and SINGH, MB., 1998. Plant homologue of human excision repair gene ERCC1 points to conservation of DNA repair mechanisms. The Plant Journal, vol. 13, no. 6, p. 823-829. http://dx.doi.org/10.1046/j.1365313X.1998.00081.x. PMid:9681020

ZAGATTO, PA. and BERTOLETTI, E., 2006. Ecotoxicologia Aquática: Princípios e Aplicações. São Carlos: Editora Rima. 464 p. 